\title{
Grzegorz Baziur
}

Małopolska Uczelnia Państwowa

im. rotmistrza Witolda Pileckiego w Oświęcimiu

\section{Dębica i powiat dębicki pod władzą Armii Czerwonej w latach 1944-1945 w aspektach społeczno-politycznym i ekonomicznym}

\begin{abstract}
Abstrakt: Artykuł poświęcony jest skutkom pobytu oddziałów Armii Czerwonej w powiecie dębickim w latach 1944-1945. Omówiono wpływ wojsk sowieckich i organów bezpieczeństwa ZSRR, przebywających na terenie tego powiatu, na sytuację społeczno-polityczną, a także na bezpieczeństwo ludności oraz życie społeczno-gospodarcze, w aspekcie rabunkowej gospodarki, zwłaszcza w sektorze rolniczym.
\end{abstract}

Słowa kluczowe: Armia Czerwona, Dębica, powiat dębicki, komuniści.

Abstract: The article deals with the effects of the stay of Red Army troops in the District of Dębica in 1944-1945. It discusses the impact of the Soviet troops and the Soviet security services staying in the district on the socio-political situation as well as on the security of the population and socio-economic life, in the aspect of predatory economy, especially in the sector of agriculture.

Key w or d s: Red Army, Dębica, Dębica district, communists.

\section{Wprowadzenie}

Dębica to miasto powiatowe położone w województwie podkarpackim, a jego historia liczy ponad 650 lat. Najstarszy dokument, wspominający o osadzie Dembicha, pochodzi z 1293 r., gdy osada ta była własnościa rodu Gryfitów. W latach zaborów Dębica znalazła się w zaborze austriackim, wówczas też nastapił upadek ekonomiczny miasta, a władze austriackie pozbawiły ja 
praw miejskich. Ożywienie gospodarcze miało miejsce w drugiej połowie XIX w., po wybudowaniu w 1856 r. linii kolejowej Kraków-Dębica-Lwów. Dzięki budowie kolei zostały w mieście tym zlokalizowane zakłady przemysłowe, a przed wybuchem I wojny światowej w 1914 r. odzyskało ono prawa miejskie.

Kolejny etap rozwoju miasta przypadł na ostatni okres II Rzeczypospolitej - w latach 1936-1939, w ramach budowy Centralnego Okręgu Przemysłowego (COP), w Dębicy powstała fabryka opon samochodowych, a w Pustkowie - zakłady tworzyw sztucznych. W 1937 r. miasto zostało siedzibą powiatu w województwie krakowskim, a tuż przed wybuchem II wojny światowej liczba mieszkańców Dębicy przekroczyła 10 tys. osób. Podczas okupacji niemieckiej w mieście znajdowały się obóz pracy przymusowej i getto. W latach 1939-1940 i w 1944 r. oddziały „ewakuacyjne” wojsk niemieckich i żandarmerii wywiozły z tamtejszych fabryk i przedsiębiorstw znaczną część surowców produkcyjnych, maszyn i urządzeń produkcyjnych, m.in. z fabryki opon samochodowych, wytwórni sztucznego kauczuku w Pustyni, walcowni metali kolorowych, fabryki materiałów wybuchowych „Lignoza” i betoniarni dębickiej, w której w zamian uruchomili produkcję konserw i wędlin, a opustoszałe hale produkcyjne zamienili na magazyny lub warsztaty remontowe. Władze niemieckie pozostawiły Państwową Przetwórnię Mięsną (PPM), która pracowała dla potrzeb żywieniowych wojsk niemieckich. W konsekwencji braku maszyn zakłady zostały unieruchomione w chwili zakończenia okupacji niemieckiej ${ }^{1}$.

Celem niniejszego artykułu jest ukazanie dziejów Dębicy w latach 19441945 - zakończenie okupacji niemieckiej trwającej od września 1939 r. i zajęcie miasta przez oddziały Armii Czerwonej 23 VIII 1944 r. Wynikały z tego określone skutki prawnoustrojowe: przechwycenie władzy przez komunistów z Polskiej Partii Robotniczej (PPR), zwalczanie i likwidacja władz administracyjnych konstytucyjnego rządu RP na uchodźstwie, liczne przestępstwa popełniane przez żołnierzy i dowódców jednostek sowieckich wobec ludności cywilnej, jak: morderstwa, gwałty, napady zbrojne, rabunki, wypadki samochodowe itp., a także rabunki mienia gospodarczego, co razem osłabiało start odbudowy zniszczonego miasta i powiatu.

$\mathrm{Na}$ temat historii miasta i powiatu dębickiego powstało wiele różnych publikacji. Pisali o niej Józef Buszko i Feliks Kiryk, Antoni Stańko, Antoni Lubiniecki, Edmund Gałas, Artur Bata i Hanna Lawera. Niezbędne okazały się też dokumenty źródłowe, ilustrujące opisywaną rzeczywistość, które uzyskałem w Archiwum Narodowym w Krakowie, Archiwum Państwowym w Rzeszowie i Archiwum Akt Nowych w Warszawie. Wśród metod, które wykorzystałem podczas badań naukowych, należy wymienić opisowa, zgodnie z która została ukazana faktografia, i statystyczna, zastosowaną do analizy

${ }^{1}$ Dębica. Zarys dziejów miasta i regionu, red. J. Buszko, F. Kiryk, Kraków 1995, s. 463-464. 
danych liczbowych zwiąanych np. z podliczeniem strat spowodowanych przez wojska sowieckie podczas przemarszów i czasowego stacjonowania $\mathrm{w}$ powiecie dębickim.

\section{Wpływ oddziałów Armii Czerwonej i sowieckich służb specjalnych na sytuację społeczno-polityczną w powiecie dębickim i ich rola w budowie podstaw totalitarnego systemu komunistycznego}

Po wyparciu wojsk niemieckich z Dębicy, 23 VIII 1944 r. wojska I Frontu Ukraińskiego zajęły samo miasto oraz wschodnią część powiatu dębickiego, kończąc okupację niemiecka. W trakcie wspomnianej operacji wojskowej wojska sowieckie były wspierane przez oddziały 5 Pułku Strzelców Konnych Armii Krajowej (AK) pod dowództwem por. Mieczysława Stachowskiego „Sępa” oraz inne oddziały AK, które działały na jego terenie, realizując zadania w ramach akcji „Burza”. Dwa tygodnie po zajęciu miasta front ustabilizował się $4 \mathrm{~km}$ od Dębicy, na linii Radomyśl-Grudna, trwając tak do stycznia 1945 r. $^{3}$

W czasie walk sowiecko-niemieckich w sierpniu 1944 i styczniu 1945 r. miasto zostało zniszczone $\mathrm{w}$ ponad $40 \%{ }^{4}$. Ze względu na działania wojenne mieszkańców 57 wsi (na ogólną liczbę 97) wysiedlono zarówno po niemieckiej, jak i sowieckiej stronie frontu, zaś znaczna część mieszkańców miasta i powiatu zimowała w piwnicach i ziemiankach, co powodowało choroby i dużą śmiertelność, zwłaszcza wśród dzieci, np. w Borowej, Dobrkowej, Kozłowie, Gołęczynie, Głowaczowej, Gumniskach i Połomii ${ }^{5}$. Ze względu na biegnąca wzdłuż Wisłoki linię frontu, do rozpoczęcia ofensywy zimowej Armii Czerwonej siedzibe powiatowych władz państwowych i samorządowych, partii politycznych przeniesiono do Ropczyc, które były w bezpiecznej odległości od linii walk, a w lutym 1945 r. wróciła do Dębicy, gdzie do września 1939 r. mieściły się władze powiatowe.

W latach 1944-1945 niestabilna była też administracyjna przynależność Dębicy, która w okresie od sierpnia 1944 do lutego 1945 r. podlegała wraz z Mielcem władzom administracyjnym w Rzeszowie, a od lutego do 7 VII

${ }^{2}$ A. Stańko, Gdzie Karpat progi... Armia Krajowa w powiecie dębickim, Warszawa 1984, s. $192-227$.

${ }^{3}$ Dębica. Zarys dziejów..., s. 500-501.

${ }^{4}$ Zob. A. Daszkiewicz, Życie polityczne w latach 1944-1948, w: Ropczyce. Zarys dziejów, red. W. Bonusiak, F. Kiryk, Rzeszów 1991, s. 409; E. Krypel, Wśród młodzieży wiejskiej, w: Ze wspomnień działaczy, Rzeszów 1966, s. 244. Zob. też: A. Bata, H. Lawera, Dębica i ziemia dębicka, Krosno 1997, s. 16. Na istniejące w 1939 r. 1743 domy 630 zostało spalonych, 420 częściowo zburzonych, a pozostały 693 domy na 10255 mieszkańców gminy Dębica. Archiwum Państwowe w Rzeszowie (dalej: APRz), Wydział Powiatowy w Dębicy 56/96, 26, Sprawozdanie z położenia Gminy Zbiorczej Dębica z 1 III 1945 r.

${ }^{5}$ W. Gościmiński, Trudny wielkiego dzieła poczatek, w: Ze wspomnień działaczy, Rzeszów 1966, s. $69-70$. 
1945 r. - ponownie województwu krakowskiemu. Na mocy dekretu Krajowej Rady Narodowej (KRN) o utworzeniu województwa rzeszowskiego (w miejsce dawnego lwowskiego) z 23 VIII 1945 r. powiat dębicki wraz z powiatami: mieleckim, jasielskim i gorlickim wszedł w skład województwa rzeszowskiego ${ }^{6}$. W zajętej przez wojska sowieckie Dębicy powstały komendantura wojenna Armii Czerwonej oraz placówka NKWD i sowieckiego kontrwywiadu wojskowego Smiersz. Celem wojskowych władz sowieckich były zarówno współpraca z powstająca pod ich polityczna kontrola administracja polska, dbałość o porządek i dyscyplinę stacjonujących na jego terenie wojsk, jak i likwidacja istniejaccych struktur Polskiego Państwa Podziemnego (PPP), oddziałów AK i Narodowych Sił Zbrojnych (NSZ). Działania te miały spowodować przechwycenie władzy przez PPR w tym powiecie, jako komunistycznego i prosowieckiego ośrodka politycznego.

Walki niemiecko-sowieckie i wysiedlenie ludności z obu stron frontu doprowadziły do niemal zupełnego zniszczenia struktur obwodu AK Dębica. Po ustabilizowaniu się frontu, po obu jego stronach zaczęła się odbudowa struktur i oddziałów AK w ramach dwóch obwodów AK Dębica. Dowódca zachodniego obwodu AK, działającego pod okupacją niemiecka, obejmującego placówki w Pilznie, Zasowie i Korzeniowie, został dotychczasowy inspektor Wojskowej Służby Ochrony Powstania Obwodu AK Dębica, kpt. Antoni Waratus „Obuch”, który pozostał na tym stanowisku do rozwiąania AK 19 I 1945 r. Po utworzeniu organizacji „NIE” („Niepodległość”) objął funkcję komendanta Obwodu Dębica, potem Delegatury Sił Zbrojnych (DSZ), a po powołaniu 2 IX 1945 r. Zrzeszenia „Wolność i Niezawisłość” (WiN) został kierownikiem Rady WiN w Dębicy?

Podobnie było na wschodnich terenach, zajętych przez Armię Czerwona, gdzie oficerowie AK także zaczęli odtwarzać obwód AK Dębica, którym dowodził dotychczasowy komendant podobwodu AK Sędziszów Małopolski, por. Mieczysław Stachowski „Sęp”, „Maciej”. Funkcję dowódcy wschodniego obwodu AK pełnił do aresztowania przez NKWD 9 IX 1944 r., a po kilkutygodniowym śledztwie był deportowany do łagrów w ZSRR ${ }^{8}$. Kolejnym komendantem obwodu został dotychczasowy dowódca placówki AK w Sędziszowie Małopolskim, ppor. Józef Naróg „Strzała”, „Ostroga”, również aresztowany przez NKWD i po brutalnym śledztwie wywieziony w głąb ZSRR. Następnymi byli: NN „Bogdan”, ppor. Antoni Cwen „Ryś”, „Roman” i ppor. Karol Stachak „Róża”, który dotrwał do rozwiązania AK w styczniu 1945 r. ${ }^{9}$ Od sierpnia 1944 do stycznia 1945 r. działania AK zostały ograniczone do odbudowy sieci konspiracyjnej przed groźbą infiltracji przez NKWD i UB oraz akcji

\footnotetext{
${ }^{6}$ DzURP, 26 VIII 1945, nr 27.

7 E. Fiołek, Przywódcy WiN-u. Antoni Waratus, ps. „Obuch”, „Bujnicz”, „Orzeł Biały”, XII 1992, nr 1215, s. 14-15.

8 A. Stańko, op. cit., s. 57.

${ }^{9}$ Dębica. Zarys dziejów..., s. 505.
} 
propagandowej przypominającej społeczeństwu, że jedyna, legalną władzą był rząd RP na uchodźstwie wraz ze strukturami krajowymi. W sytuacji okupacji sowieckiej PPP bojkotowało władze pochodzące z sowieckiego mandatu oraz mobilizację do Wojska Polskiego (WP), utworzonego pod auspicjami komunistów w ZSRR, dowodzonego przez gen. Zygmunta Berlinga ${ }^{10}$.

W celu skutecznego zwalczania przez komunistów struktur AK na ziemi rzeszowskiej Sowieci skierowali grupy operacyjne funkcjonariuszy z ośrodka NKWD w Kujbyszewie, wsparte przez partyzantów 1 Brygady Armii Ludowej im. Bartosza Głowackiego oraz pełnomocnika Resortu Bezpieczeństwa Polskiego Komitetu Wyzwolenia Narodowego (PKWN) mjr. Mieczysława Broniatowskiego, którzy 20 sierpnia wylądowali na podrzeszowskim lotnisku Jasionka. „Kujbyszewiacy” i partyzanci Armii Ludowej tworzyli komunistyczne organa bezpieczeństwa w południowo-wschodnim regionie Polski Lubelskiej, stąd też jako przyszli funkcjonariusze UB zostali skierowani do placówek terenowych ${ }^{11}$.

Funkcjonariusze Powiatowego Urzędu Bezpieczeństwa Publicznego (PUBP) w Dębicy od początku działalności przystapili do zwalczania AK w podlegajaccym im rejonie, a wielu gorliwie współpracowało bezpośrednio z placówka NKWD w Ropczycach, a od stycznia 1945 r. w Dębicy ${ }^{12}$. Oprócz komunistów, z PKWN i Sowietami zaczęła też kolaborować część ludowców i socjalistów, którzy również wydawali w ręce NKWD i UBP lokalnych działaczy PPP i żołnierzy AK. W wyniku haniebnych praktyk w drugiej połowie 1944 i w 1945 r. NKWD, PUBP i milicja aresztowały kilkuset oficerów i żołnierzy AK, spośród których ok. 150 osób deportowano do ZSRR. Wśród nich jedna osoba została osadzona w Riazaniu, 116 - w Borowiczach, 24 - w Stalinogorsku, a wobec 9 osób nie ustalono miejsca ich internowania. Podczas zesłania zmarło 26 osób, a lista deportowanych oficerów i żołnierzy AK z Obwodu Dębica nie jest pełna ${ }^{13}$.

${ }_{10}$ Ibidem, s. 507.

11 Spośród „kujbyszewiaków” do Sędziszowa i Ropczyc został skierowany pchor. Zenon Kiwerski, który zastapił już urzędującego w Ropczycach szefa PUBP Dębica, Walentego Szeligę, pochodzącego z Wiśniowej, zaś zastępcą Kiwerskiego był Ludwik Zawiślak z Zagorzyc, a szefem Referatu Śledczego - Tadeusz Andrusiewicz. A. Lubiniecki, Organizacja i dziatalność organów bezpieczeństwa publicznego na Rzeszowszczyźnie w latach 1944-1946, w: Materiaty z sesji popularnonaukowej poświęconej zagadnieniom ksztattowania się władzy ludowej na Rzeszowszczyźnie, Rzeszów 1966, s. 220.

12 Do głównych renegatów należeli: Stanisław Ciołek (Ciszewski), Franciszek Cyzio, Walenty Dzięgiel, Andrzej Fąfara, Jan Filipek, Leon Gurga, Michał Jewiarz, Antoni Kopeć, Stanisław Kosydar, Jan Łysek, Paweł Niedbalec, Stefan Niwa, Stanisław Szafrański, Jan Wilczyński, Feliks Zawiślak, a także funkcjonariusze MO: Pacia z Bystrzycy i Czaja z Nockowej. Wśród konfidentów NKWD znajdowali się również miejscowi komuniści, byli członkowie Komunistycznej Partii Polski, Józef i Władysław Kurowscy, którzy zadenuncjowali wielu żołnierzy Obwodu AK Dębica. Z tego powodu Sowieci deportowali ich do łagrów w Związku Sowieckim. Dębica. Zarys dziejów..., s. 507.

${ }^{13}$ Ibidem, s. 507, 530. 
Niektórzy aresztowani dowódcy i żołnierze obwodu AK Dębica zginęli w niejasnych okolicznościach, jak np. zatrzymani przez UB jesienią 1944 r. w Ropczycach: Zdzisław Brunowski „Cygan”, Zdzisław Łaskawiec i Z. Zamróz, którzy zostali zamordowani przez Sowietów na mocy wyroku Trybunału Wojennego I Frontu Ukraińskiego prawdopodobnie w Lesie Turzańskim pod Sokołowem Małopolskim, gdzie w ziemiankach mieściło się przyfrontowe więzienie NKWD $^{14}$. Po rozwiazzaniu AK 19 I 1945 r., 5 lutego komendant Podokręgu AK Rzeszów mjr Stanisław Pieńkowski „Hubert” wydał rozkaz rozwiąujący AK w terenie i przekształcający jej struktury w „NIE”. Wśród członków tej organizacji, której nazwa została zmieniona w maju 1945 r. w DSZ, a we wrześniu w WiN, byli też oficerowie i żołnierze byłego obwodu AK Dębica ${ }^{15}$.

W lutym 1945 r. inspektor Inspektoratu Rejonowego AK w Rzeszowie, mjr Łukasz Ciepliński „Pług” przekazał dowództwo Adamowi Lazarowiczowi „Pomorskiemu”, zaś komendantem obwodu „NIE”/DSZ Dębica był kpt. Antoni Waratus „Obuch”. W warunkach narastającego terroru ze strony NKWD i UBP działalność obu organizacji ograniczała się do akcji ochronnych, w tym pomocy finansowej byłym żołnierzom AK, rodzinom aresztowanych akowców, oraz propagandowo-wywiadowczych, jak np. ujawniania znanych konfidentów NKWD lub UBP, a ożywienie działalności nastapiło po powstaniu WiN.

Teren powiatu dębickiego (Rady WiN) należał do rejonu mieleckiego „Północ”16, który podlegał Rzeszowskiemu Okręgowi Rzeszowskiemu WiN ${ }^{17}$, a tenże pod Obszar Południowy WiN, nad którym pieczę sprawował Zarząd Główny Zrzeszenia. Oprócz Rady Dębica do rejonu należały Rady Mielca, Tarnobrzega i Niska. Na czele Rady w Dębicy stał do lipca 1946 r. kpt. A. Waratus „Bujnicz”, a po nim Jakub Kusibab. W ramach działalności Rada prowadziła akcję informacyjna dotycząca sytuacji społeczno-politycznej i ekonomicznej w powiecie, zachowań wojsk sowieckich, oddziałów Korpusu Bezpieczeństwa Wewnętrznego, UBP i MO, oraz propagandowa, kolportując pisma „Ku Wolności” i „Orzeł Biały”18. W ramach akcji samoobrony patrole „Straży” WiN zlikwidowały ppor. Ludwika Bojanowskiego oraz wójta Gminy Zbiorowej Dębica, Henryka Dybowskiego z Pustyni ${ }^{19}$. Na przełomie lat 1946-1947 dębickie struktury WiN zostały zlikwidowane przez funkcjonariuszy UBP.

14 J. Jaśniak, Tajemnica lasu Turzańskiego, „Katolik”, 26 VIII 1990, nr 34 (409), s. 1, 8-9.

${ }^{15}$ Dębica. Zarys dziejów..., s. 507.

${ }^{16} \mathrm{Na}$ jego czele stali kolejno: były komendant Obwodu AK Dębica, mjr Ludwik Marszałek „Michał”, N. Petryszka „Adam” i NN „Grzegorz”. Informator o nielegalnych antypaństwowych organizacjach $i$ bandach zbrojnych działajacych $w$ Polsce Ludowej w latach 1944-1956, Warszawa 1964, s. 114.

${ }^{17}$ Na czele Okręgu Rzeszowskiego stali: Adam Lazarowicz „Aleksander”, Bronisław Wochanak „Andrzej” i Władysław Koba „Marcin”, „Tor”, „Żyła”. Ibidem.

${ }_{18}$ G. Ostasz, O WIN-owskim kolportażu w Okręu Rzeszów, „Orzeł Biały” 1993, nr 6 (21), s. 9-10.

19 Bojanowski był jednym z katów Wojewódzkiego Urzędu Bezpieczeństwa Publicznego w Rzeszowie, „kujbyszewiakiem” odpowiedzialnym za śmierć oficera dywersji Inspektoratu AK Rzeszów, Wiktora Błażewskiego „Orlika”. W. Gościmiński, op. cit., s. 81. 
Obok środowisk poakowskich walkę zbrojną i polityczna przeciwko Sowietom i ich kolaborantom podją również obóz narodowy, uważający od zwycięstwa Armii Czerwonej pod Stalingradem, że w perspektywie najbliższych lat głównym wrogiem Polski nie będą już osłabione i pokonane Niemcy, a ZSRR. Należy zaznaczyć, że najwięcej oddziałów zbrojnych polskiego podziemia niepodległościowego w Rzeszowskiem, także w powiecie dębickim wywodziło się z tego środowiska politycznego - Narodowej Organizacji Wojskowej (NOW), potem Narodowego Zjednoczenia Wojskowego (NZW), lub kontynuowały działalność niepodległościową NSZ.

W lecie $1944 \mathrm{r}$. tereny powiatów dębickiego i mieleckiego, które wchodziły w skład Podokręgu NOW Tarnów, kryptonim „Sancta Maria”, należącego do Okręgu Krakowskiego NOW, zostały odcięte przez linię frontu od obu dowództw i z tego powodu przejęte przez Okręg Rzeszowski NOW. W sierpniu 1944 r. Okręg Rzeszowski został podzielony na cztery inspektoraty: „Janina” (powiaty: Jarosław, Lubaczów, Przemyśl), „Hanka” (powiaty: Przeworsk, Łańcut, Nisko), „Maria” (powiaty: Dębica, Mielec, Tarnobrzeg) i „Zofia” (powiaty: Sandomierz, Staszów, Opatów, Ostrowiec), chociaż ostatni ukształtował się ostatecznie na początku $1945 \mathrm{r}$. Po przekształceniu się NOW w NZW poszczególne struktury terenowe NOW podporządkowały się tej decyzji, zaś powiat dębicki, mający kryptonim „Patoka”, zmienił go na „Zenon”, a na jego czele staną Adam Przybyło ${ }^{20}$.

$\mathrm{Na}$ sytuację ruchu narodowego w powiatach dębickim i mieleckim oddziaływały wydarzenia związane z podziemną działalnościa środowiska narodowego w kraju w latach 1945-1947, w tym nieudana próba legalizacji, chociaż po powstaniu Tymczasowego Rządu Jedności Narodowej (TRJN) Komenda Główna (KG) NSZ początkowo go nie uznała, uważając zmiany za pozorne. Jednakże w perspektywie braku konfliktu między ZSRR a państwami zachodnimi jej oficerowie uznali ewolucyjność zmian sytuacji w kraju, co doprowadziło do likwidacji NSZ jako organizacji wojskowej. W związku z tym narodowcy zamierzali zwiększyć udział członków w polityce, administracji i gospodarce kraju oraz w osadnictwie członków NSZ na ziemiach zachodnich, powołując w tym celu Komitet Ziem Odzyskanych ${ }^{21}$. Prawdopodobnie w związku z tym gen. Zygmunt Broniewski 5 VII 1945 r. wydał rozkaz, aby zawiesić działalność oddziałów NSZ, choć oficjalnie stwierdził, że powodem decyzji były trudności organizacyjne, a o przeprowadzeniu akcji miała decydować Komenda Okręgu ${ }^{22}$. W oczekiwaniu na powrót z Londynu oddziały prowadziły akcje zbrojne, np. rekwizycje pieniędzy na cele organizacji ${ }^{23}$.

${ }^{20}$ Dębica. Zarys dziejów..., s. 513.

${ }^{21}$ L. Kulińska, Narodowcy. Z dziejów Obozu Narodowego w Polsce w latach 1944-1947, Kraków 1999, s. 135-136.

${ }^{22}$ Z.S. Siemaszko, Narodowe Sity Zbrojne, Londyn 1982, s. 177. Por. T. Wolfram, Koniec NSZ, „Karta” 1991, nr 3, s. 107.

${ }^{23}$ M. Korkuć, „Zostańcie wierni tylko Polsce...” Niepodległościowe oddziały partyzanckie w Krakowskiem (1944-1947), Kraków 2002, s. 278. 
Działacze polityczni, jak i dowódcy oddziałów narodowych wiązali też nadzieję na wyjście z podziemia z próbą legalizacji nurtu narodowego w powojennej Polsce przez Tadeusza Kobylańskiego i powstały Komitet Legalizacyjny (KL), jednakże ze względu na brak woli politycznej ze strony komunistów, w tym samego prezydenta KRN Bolesława Bieruta, sprawa zakończyła się niepowodzeniem, a zarówno działacze Komitetu, jak i wielu polityków Stronnictwa Narodowego (SN) oraz dowódców i żołnierzy NSZ i NOW/NZW zostało aresztowanych przez komunistyczne organa bezpieczeństwa ${ }^{24}$. W istniejącej sytuacji KG NSZ przeprowadziła tajną demobilizację oddziałów leśnych, pod koniec 1945 r. zaś NKWD rozbiło struktury KG, a część dowódców, którzy uniknęli aresztowań, weszła do powstałego w grudniu 1944 r. NZW ${ }^{25}$. Nie pomogły też próby likwidacji narodowych struktur wojskowych z inicjatywy części działaczy narodowych, omawiane podczas rozmów kuriera prezesa SN Tadeusza Bieleckiego, Edwarda Sojki oraz próba utworzenia partii narodowo-katolickiej, podjęta przez Adama Doboszyńskiego ${ }^{26}$.

Po podporządkowaniu NSZ strukturom NZW, w powiatach dębickim i mieleckim rozpoczą się szczytowy okres działalności wojskowej konspiracji narodowej, w stosunku do dość skromnej w okresie okupacji niemieckiej. Prawdopodobnie było to też przyczyną rozwiązania w styczniu 1944 r. Okręgu IV NSZ Rzeszów, a powiaty tworzące ten okręg - wśród nich dębicki - weszły w skład Krakowskiego VII Okręgu NSZ27. Wiele oddziałów leśnych, które działały we wspomnianych powiatach, reprezentowało proweniencję narodowa, a od drugiej połowy $1945 \mathrm{r}$. wszystkie one miały rodowód narodowy i były podporządkowane NSZ lub NZW, posiadając silne poparcie wśród miejscowej

${ }^{24}$ W lipcu 1945 r. Tadeusz Kobylański odbył rozmowy dotyczące legalizacji SN z premierem TRJN, Edwardem Osóbka-Morawskim, a po zakończeniu został utworzony KL, na czele którego stanęli Stanisław Rymar i Jan Bielawski. Wiosną 1945 r. ujawnili się też działacze Biura Ziem Nowych Delegatury Rządu, wśród których wielu należało do konspiracyjnego SN, a jego ujawnienie poparł przybyły z Londynu Stanisław Grabski. Ze względu na brak woli politycznej i wrogość prezydenta KRN, Bolesława Bieruta i jego sowieckich mocodawców działacze KL SN nie zostali jednak przyjęci przez Bieruta i Osóbkę-Morawskiego, natomiast w okresie między sierpniem a październikiem zostali aresztowani przez funkcjonariuszy UB. A. Paczkowski, Pót wieku dziejów Polski 1939-1989, Warszawa 2005, s. 109.

${ }^{25}$ Narodowe Zjednoczenie Wojskowe, w: Żotnierze wyklęci. Antykomunistyczne podziemie zbrojne po 1944 roku, red. G. Wassowski, L. Żebrowski, Warszawa 1999, s. 141-215; Z.S. Siemaszko, op. cit., s. 178; W. Rojek, Stronnictwo Narodowe (SN) „Kwadrat”, w: Stownik historii Polski, Kraków 1996, s. 203-209.

${ }^{26}$ Edward Sojka reprezentował rząd RP na uchodźstwie. Z jego inicjatywy w grudniu $1945 \mathrm{r}$. zostało powołane podziemne Prezydium SN, które działało do likwidacji przez UB na przełomie 1946 i 1947 r. W grudniu 1946 r. do Polski przyjechał również nielegalnie z Londynu Doboszyński, który zamierzał utworzyć partię narodowo-katolicka, ale w 1947 r. został aresztowany i postawiony przed Wojskowym Sądem Rejonowym (WSR), który skazał go na wieloletnie więzienie. W. Frazik, $Z$ dziejów taczności cywilnej Kraj-emigracja w latach 1944/1945-1948/1949, „Zeszyty Historyczne WiN-u” 1998, nr 11, s. 35.

${ }_{27}$ Zob. T. Biedroń, Okreg Krakowski Narodowych Sit Zbrojnych w latach 1945-1946, „Zeszyty Historyczne WiN-u" 1993, nr 3, s. 53. 
ludności, zwłaszcza na wsiach, i wśród lokalnego duchowieństwa katolickiego, niechętnie lub wrogo traktujących komunistów i oddziały sowieckie dokonujące grabieży, gwałtów i zabójstw miejscowej ludności ${ }^{28}$.

Działalność antysowiecka i antykomunistyczna prowadził oddział Jana Stefki „Mściciela” w powiatach: dębickim, mieleckim i brzozowskim. W lutym 1946 r. oddział liczacy 35 ludzi przechodził z terenu powiatu jasielskiego przez gminy: Wielopole Skrzyńskie, Ropczyce i Sędziszów Małopolski. Podczas marszu w miejscowości Borek Wielki spotkał dwóch funkcjonariuszy PUBP w Dębicy: Stanisława Kosydara i Walentego Dzięgiela. Obu ubeków partyzanci zlikwidowali, a ich zwłoki zostawili w leśnym bunkrze ${ }^{29}$. Następnie dokonali akcji w majątku państwowym w Przecławiu, gdzie odebrali srebrne sztućce rodowe Reyów, które bezprawnie przywłaszczył sobie miejscowy aktywista PPR, Alojzy Popiel ${ }^{30}$. Po tych akcjach oddział pomaszerował w nocy przez Dębicę w kierunku Grudnej w powiecie jasielskim, gdzie zatrzymał się na kwaterach. Po uzyskaniu informacji o postoju oddziału od miejscowego konfidenta funkcjonariusze PUBP z Dębicy wraz z milicją i oddziałami ludowego WP zorganizowali obławę, podczas której zginęło 4 partyzantów, 16 zostało ujętych, a ranny „Mściciel” wraz z pozostałymi ludźmi przebił się przez pierścień okrażenia. Funkcjonariusze PUBP pod dowództwem szefa, kpt. Juliana Wojtusiaka, nadal ich ścigali, a szczególną gorliwością odznaczali się M. Jewiarz, J. Jończyk i Ochała, którzy prowadzili też brutalne śledztwo przeciw aresztowanym osobom ${ }^{31}$.

Podczas pogrzebu zlikwidowanych funkcjonariuszy PUBP w Dębicy, zastępca jego szefa, który przemawiał nad ich trumnami, zapowiedział, że partyzanci - w języku nienawiści klasowej - „bandyci”, którzy zastrzelili Kosydara i Dzięgiela, zostana publicznie straceni ${ }^{32}$. Zgodnie z zapowiedzia w targową środę, 10 VII 1946 r., na dębickim rynku odbyła się publiczna egzekucja dwóch żołnierzy oddziału „Mściciela”: 25-letniego Józefa Grębosza, brata zamordowanego przez UB Bronisława Grębosza z Tuszymy i 24-letniego Józefa Kozłowskiego, pochodzącego z Miejsca Piastowego, a także 24-letniego Franciszka Nostera. Podczas egzekucji katem był Świeca pochodzący z Kędzierza, a zwłoki partyzantów potajemnie pochowano na dębickim cmentarzu, zaś miejsce ich pochówku zostało oznaczone przez miejscowych członków WiN-u. W późniejszym czasie postawiono nagrobek z wymownym napisem: „Za wolność i niepodległość. Partyzanci AK” ${ }^{33}$. W celu zastraszenia

${ }^{28}$ Dębica. Zarys dziejów..., s. 513.

29 J. Dymitrowski, Publiczna egzekucja w Dębicy, cz. 2, s. 6, https://glos24.pl/glos24/region-debicki/wiadomosci/item/8173-publiczna-egzekucja-w-d\%C4\%99bicy-cz-2 (dostęp: 10 VIII 2018).

${ }_{30}$ M. Maciaga, Sprawa trzech od „Mściciela”, „Katolik”, 24 XI 1989, nr 39 (362), s. 8.

31 J. Jaśniak, op. cit., s. 10.

${ }^{32}$ W. Gościmiński, op. cit., s. 82.

${ }^{33} \mathrm{~W}$ „Wokandzie” podano nieprawdziwą informację o zamordowaniu ich w więzieniu w Rzeszowie. „Wokanda”, 1 VII 1990, nr 15; 30 IX 1990, nr 28; 20 I 1991, nr 3. Zob. J. Jaśniak, op. cit., s. 10. 
mieszkańców miasta, w tym przybyłych na targ rolników, egzekucja miała charakter publiczny, a ludzie zostali zgromadzeni wokół ustawionych na rynku szubienic. Wśród tłumu była też młodzież szkolna ze starszych klas ${ }^{34}$.

Dzięki fotografii wykonanej podczas egzekucji przez szefa wywiadu Rady Dębickiej WiN Józefa Steca „Joda” i lekarza, dr. Stefana Zdanowskiego „Wojaka”, którzy obserwowali egzekucję z balkonu domu Antoszewskich, informacja o zbrodni szybko obiegła Polskę i świat. Zdjęcie zostało przekazane kanałami konspiracyjnej łaczności WiN do Londynu i pokazane w krajach Wolnego Świata. Po jego publikacji w prasie zachodniej PUBP w Dębicy podją śledztwo, a dzięki konfidentom obaj zostali aresztowani i poddani śledztwu, a następnie skazani przez WSR w Rzeszowie na kary więzienia ${ }^{35}$.

Oprócz oddziału „Mściciela”, w 1945 r. Jan Dec, mieszkający w Dębicy, wraz z Janem Pękala z Grabin wysłał do lokalnych komunistów i sowieckich kolaborantów upomnienia i wyroki śmierci. Otrzymali je: Dominik Kamoński, Michał Bieszczad, Stanisław Ryba, Stefan Pietruszka, Tadeusz Kędzielawa, Czesław Anioł, Jakub Róg, Michał Jewiarz, Michał Borowiec, Franciszek Babicz, Stanisław Cholewa, Jan Przywara, Leopold Acedoński, Jan Dumanowski, Michał Kalinowski i Franciszek Żmuda ${ }^{36}$. W 1945 r. w gminach Wielopole Skrzyńskie, Dębica i Ropczyce działał też oddział zbrojny, liczący 30 ludzi, pod dowództwem Józefa Lipy, którego zastępcą był Pelczar ${ }^{37}$. Członkowie oddziału zlikwidowali kilka osób kolaborujących z Sowietami, władzami komunistycznymi i UBP. Oddział Lipy prowadził też działania antysowieckie w powiatach jasielskim, krośnieńskim i rzeszowskim, jednak po jego rozpracowaniu przez PUBP w Dębicy obaj dowódcy zostali aresztowani w 1946 r. w Niedźwiadzie ${ }^{38}$. Wśród innych grup i oddziałów podziemia niepodległościowego należy też wspomnieć o grupie Władysława Majki, który zabił funkcjonariusza MO z Kozodrzy, Władysława Szkutaka. Oddział został zlikwidowany przez PUBP po skrytobójczej śmierci dowódcy, a jego żołnierze trafili do więzienia lub zaprzestali dalszej działalności ${ }^{39}$.

Na terenach gmin Borek Wielki, Ropczyce i Paszczyna działał też liczący 20 osób oddział pod dowództwem Józefa Golonki. Jego członkowie wymierzali głównie karę chłosty zbyt gorliwym członkom PPR, jednak po amnestii z 22 II 1947 r. Golonka ujawnił się, ale ponieważ nie ufał w szczerość komunistów, nie oddał broni. Na swoje nieszczęście w miejscowości Czekaj Golonka spotkał

\footnotetext{
${ }^{34}$ J. Jaśniak, op. cit., s. 10.

${ }^{35}$ Ibidem.

${ }^{36}$ W. Gościmiński, op. cit., s. 64.

${ }^{37}$ Ibidem, s. 66, 80-81.

${ }^{38}$ Wśród zlikwidowanych kolaborantów byli m.in.: zastrzelony jesienią 1944 r. Józef Budziwojski z Nawsia, Wacław Szeliga z Iwierzyc (wiosna 1945 r.), aktywista PPR z Łączek Kucharskich, Władysław Marć (wrzesień 1945 r.) i wspomniany wójt Gminy Zbiorowej Dębica, Henryk Dybowski (jesień 1945 r.). Ibidem, s. 66, 81.

${ }^{39}$ Ibidem, s. 81.
} 
funkcjonariusza PUBP w Dębicy, Michała Jewiarza, na którego widok sięgną po broń, jednak ubek był szybszy i strzałem pozbawił go życia ${ }^{40}$. Po uzyskaniu informacji od konfidentów o przybyciu z powiatu jasielskiego oddziału partyzanckiego pod dowództwem Jaracza w rejon leśniczówki Kamionka-Żdżary, gdzie kwaterował, w kwietniu 1946 r. funkcjonariusze MO i PUBP w Dębicy rozbili ten oddział ${ }^{41}$.

Oprócz walki politycznej i zbrojnej polityków obozu komunistycznego przeciw AK, działacze PPR, wraz z partiami koncesjonowanymi, głównie Polska Partia Socjalistyczną (PPS) i Stronnictwem Ludowym (SL) „Wola Ludu" rozpoczęli przygotowania do utworzenia w powiecie dębickim struktur administracji podległej politycznie PPR. Początkowo życie polityczne rozwijało się poza Dębica - wpływ na to miały rolniczy charakter powiatu i brak wśród mieszkańców przygotowania do działalności politycznej, choć historycy twierdzą że nieinteresowanie się mieszkańców działalnością polityczną było spowodowane bliskością frontu ${ }^{42}$. Uwzględniając powyższe okoliczności, członkowie komórek terenowych PPR, zaś w Wielopolu Skrzyńskim Organizacji Walki z Okupantem, przystapili do legalnej działalności, czego przejawem było zorganizowane w Ropczycach w październiku 1944 r. spotkanie działaczy partii z terenu powiatu dębickiego ${ }^{43}$. Po podjęciu ofensywy zimowej i wypędzeniu $\mathrm{z}$ terenu powiatu dębickiego wojsk niemieckich doprowadzono do wzrostu liczby członków PPR - z 70 do 400, którzy skupili się organizacyjnie w kołach (komórkach) działających na wsiach, w Ropczycach i Sędziszowie ${ }^{44}$.

W tym czasie w Dębicy organizacją życia i mobilizacja mieszkańców do działalności politycznej zajęła się miejscowa inteligencja. Jak można sądzić z przebiegu wypadków, z inspiracji przewodniczącego Delegatury PKWN na Małopolskę, a zarazem wojewody rzeszowskiego dr. Wiktora Jedlińskiego, sowiecki komendant wojenny zlecił utworzenie Zarządu Miejskiego adwokatowi Stanisławowi Nagawieckiemu, co nie stanowiło przypadkowego wyboru, gdyż znany był on zarówno w Dębicy, jak i Moskwie ${ }^{45}$.

${ }^{40}$ Ibidem.

${ }^{41}$ Ibidem, s. 81-82.

${ }^{42}$ Zob. E. Gałas, Tak rodzita się władza ludowa w Dębickiem, w: Materiaty z sesji popularnonaukowej..., s. 253.

${ }^{43}$ Inicjatorami spotkania byli miejscowi aktywiści PPR - Maksymilian Budziwojski oraz bracia Piotr i Michał Chłędowscy. Uczestnicy spotkania reprezentowali ok. 70 członków partii, a w jego wyniku powołali Komitet Powiatowy PPR pod przewodnictwem I sekretarza Budziwojskiego. A. Daszkiewicz, Międzypartyjne stosunki polityczne w Polsce Południowo-Wschodniej (lata 1944-1947), Rzeszów 1987, s. 74.

${ }^{44}$ E. Gałas, Rola PPR w budowie władzy ludowej w pow. Dębica, w: Działalność PPR na Ziemi Rzeszowskiej (szkice, opracowania, wspomnienia), red. B. Syzdek, Warszawa 1976, s. $181-184$.

45 Jedliński podczas I wojny światowej walczył na froncie wschodnim i dostał się do niewoli bolszewickiej. Po przesłuchaniu przez Feliksa Dzierżyńskiego w 1919 r. został zwolniony i powrócił do kraju. Poza tym był on znany w mieście jako profesor miejscowego gimnazjum, 
Po przyjęciu powierzonego zadania Nagawiecki ściagnął do pracy przedwojennych samorządowców, organizując 24 VIII zebranie wybranych i nieobciążonych współpracą z okupantem mieszkańców, którzy utworzyli wówczas Miejską Radę Narodowa (MRN) i wybrali go na jej przewodniczącego oraz burmistrza Dębicy ${ }^{46}$. Mimo że radni nie złożyli żadnej deklaracji, realizowali zadania wynikające z założeń Manifestu PKWN i władz wojewódzkich, m.in. współpracowali przy organizacji w mieście Milicji Obywatelskiej (MO, która zastapiła przedwojenną Policję Państwowa), za co odpowiadał radny Stanisław Wiącek. Funkcjonariusze MO, przy pomocy żołnierzy z sowieckiej komendantury wojennej, czuwali nad bezpieczeństwem, jak i mieniem mieszkańców. Władze zorganizowały również opiekę lekarska. Po rozpoczęciu ofensywy zimowej 1945 r., władze miejskie włączyły się do prac organizacyjnych i propagandowych, prowadzonych przez powołaną Rejonową Komendę Uzupełnień (RKU), na rzecz poboru do WP roczników 1924-193147. Pojawił się jednak pewien problem, który wynikał z faktu, że wspomniani działacze Zarządu Miejskiego - mimo wykonywania dyrektyw PKWN - nie identyfikowali się z obozem PPR, chcac przeczekać napór sowiecki, po czym budować demokratyczny ład i porządek na podległym im terenie.

Działacze PPR, zaniepokojeni rozwojem sytuacji dokonującym się w mieście bez ich udziału i kontroli, działając samowolnie, 27 IX powołali w Sędziszowie Powiatowa Radę Narodowa (PRN). Przewodniczącym PRN został Ludwik Biduś, który pełnił tę funkcję do stycznia 1945 r., a po nim wybrano Walentego Szeligę. Na pierwszym posiedzeniu PRN zatwierdziła też kandydaturę członka PPR, Piotra Chłędowskiego, na stanowisko starosty, zaś Franciszka Dygonia z SL - na wicestarosty ${ }^{48}$. Mimo braku uprawnienia Rada dokonała wyboru burmistrza miasta, którym został przedwojenny działacz PPS, Franciszek Ziemiowski, reprezentujacy Dębicę w Radzie. Działania doprowadziły do ostrego konfliktu z wojewoda, którego komuniści nie akceptowali za jego antykomunistyczne poglądy ${ }^{49}$. W tym samym czasie zostało utworzone Starostwo Powiatowe w Dębicy, na czele którego stanął członek PPR, Chłędowski. 10 października, podczas narady PPR, Chłędowski odniósł się do tej sprawy, a ostatecznie konflikt zakończył się zwycięstwem działaczy PPR i w listopadzie odwołaniem Jedlińskiego przez Bieruta ze wszystkich pełnionych

gdzie pracował do 1927 r.; czynnym sportowcem i działaczem Klubu „Wisłoka” oraz prezesem Związku Wędkarskiego. W latach 1928-1934 był działaczem i prezesem Koła Miejskiego Bezpartyjnego Bloku Współpracy z Rządem i z tej racji pełnił obowiązki burmistrza miasta, a w 1937 r. otworzył i prowadził na terenie Ropczyc kancelarię adwokacka. Dębica. Zarys dziejów..., s. 532.

${ }^{46}$ E. Gałas, Rola PPR..., s. 189-190.

${ }^{47}$ Dębica. Zarys dziejów..., s. 533.

${ }^{48}$ E. Gałas, Rola PPR..., s. 185-186.

${ }^{49}$ Archiwum Akt Nowych (dalej: AAN), Komitet Centralny Polskiej Zjednoczonej Partii Robotniczej (dalej: KC PZPR), 295/IX/290, Sprawozdanie opisowe „Jasnego”, 7 IX 1944 r. 
funkcji50. Mimo uzyskanego poparcia od Bieruta oraz upoważnienia podpisanego przez członka Delegatury, dr. Stanisława Skrzeszewskiego i komendanta wojewódzkiego MO, płk. Franciszka Księżarczyka, Chłędowski i Maksymilian Budziwojski na terenie miasta podjęli działalność dopiero po rozpoczęciu ofensywy styczniowej, w momencie małej aktywności oddziałów AK. Wynikała ona m.in. z „Wytycznych na okres zimowy 1944/1945 r.”, w których komendant główny AK gen. Leopold Okulicki „Niedźwiadek” zalecił: „wkraczającym władzom sowieckim nie ujawniamy ani AK, ani władz administracyjnych" ${ }^{51}$.

Po rozpoczęciu ofensywy i zakończeniu okupacji niemieckiej w pozostałej części powiatu, w lutym jego władze przeniosły swoją siedzibę z Ropczyc do Dębicy. Zmieniło to dotychczasowa pozycję mieszkańców miast. Stali się oni przedmiotem bardzo intensywnej indoktrynacji ze strony partii politycznych, które przeniosły też do tego miasta swoje siedziby. Brak partii na terenie miasta spowodował, że chwilowo PPR nie zmieniła burmistrza, co doprowadziło do pewnego rodzaju dwuwładzy w mieście. Na mocy decyzji Komitetu Powiatowego PPR oraz PRN obowiązki burmistrza, wykonywane przez Nagawieckiego, zostały ograniczone, a ich realizacja zlecona Ziemiowskiemu. Dopiero po organizacji w Dębicy kilku kół PPR i wynikającej z tego możliwości dokonania zmian w składzie MRN, w kwietniu 1945 r. Nagawiecki został oficjalnie burmistrzem Dębicy ${ }^{52}$. Wolne do tej pory od walk partyjnych MRN i Zarząd Miejski wraz burmistrzem Nagawieckim dzięki swej pracy stabilizacyjno-organizacyjnej stworzyli dobre warunki do rozwoju aktywności politycznej wśród mieszkańców miasta, jednak rolniczy charakter miasta i powiatu sprawił, że dla partii robotniczej, za jaką uważała się PPR, nie było bazy społecznej zapewniającej jej rozwój. Stosunkowo nieliczni robotnicy zatrudnieni w PKP - Stacja Dębica i w Zakładach Gumowych przed wojną należeli głównie do PPS lub SL bądź byli sympatykami tych partii. Istniejace warunki zadecydowały, że w pracach Komitetu Wojewódzkiego (KW) PPR w Rzeszowie miasto i powiat zaliczone zostały w województwie do III Okręgu, obejmującego powiaty rolnicze, do którego obsługi KW przydzielił Jana Sabika ${ }^{53}$.

Po przyjeździe władz w Dębicy miejscowi działacze PPR rozpoczęli budowę struktur organizacji partyjnej, a pierwsza jej komórką było Koło PPR, powstałe jeszcze w 1944 r. w Ropczycach, które skupiało funkcjonariuszy PUBP i MO ${ }^{54}$.

${ }^{50}$ S. Dobosz, Przemiany polityczno-społeczne w Matopolsce Środkowej w latach 1944-1950, Rzeszów 1990, s. 213-215. Por. E. Gałas, Rola PPR..., s. 184.

${ }^{51}$ Polskie Sity Zbrojne $w$ drugiej wojnie światowej, t. III: Armia Krajowa, Londyn 1950, s. 910-914.

${ }^{52}$ APRz, Miejska Rada Narodowa w Dębicy (dalej: MRN), 1, Protokoły posiedzeń MRN z 1945 r.

${ }^{53} \mathrm{APRz}$, Komitet Wojewódzki Polskiej Zjednoczonej Partii Robotniczej (dalej: KW PZPR), 1/VI/2, Sprawozdanie Wydziału Organizacyjnego KW PPR w Rzeszowie, 15 VII-15 VIII $1945 \mathrm{r}$.

${ }^{54}$ E. Gałas, Rola PPR..., s. 182. 
Kolejne koło - „urzędnicze” - utworzyli pracownicy Komitetu Powiatowego (KP) i Starostwa. Mimo pracy werbunkowej nadal brakowało widocznych osiagnięć w rozwoju organizacyjnym, a niepowodzenia w tym zakresie II sekretarz Komitetu Powiatowego Piotr Karbarz motywował źle prowadzona agitacja i werbunkiem oraz brakiem sprawnie działającego Komitetu Miejskiego ${ }^{55}$. Ponadto wskutek braku prawnej regulacji przynależności powiatu do województwa rzeszowskiego i nieporozumienia, jakie na tym tle istniało z władzami województwa krakowskiego, KP PPR czuł się zagubiony. Jego pracowników wzywano na narady zarówno do Krakowa, jak i Rzeszowa, a Budziwojski był nawet członkiem Egzekutywy KW PPR w Krakowie, członkiem zaś Egzekutywy KW PPR w Rzeszowie - starosta Chłędowski. Obie instancje wojewódzkie PPR starały się wpływać na pracę partyjną w powiecie dębickim.

Zarówno do ożywienia aktywności, jak i rozwoju ilościowego PPR doszło po ostatecznym rozstrzygnięciu przez KRN przynależności powiatu dębickiego do województwa rzeszowskiego po 7 VII 1945 r. Mimo ofensywnego działania i włączenia do pracy na tym odcinku utworzonego Komitetu Gminnego w Dębicy, wyniki były nikłe, a do końca 1945 r. udało się utworzyć kilkuosobowe tzw. Miejskie Koło Budowlanych przy Powiatowym Biurze Odbudowy, z sekretarzem Edwardem Szpunarem na czele oraz 32-osobowe koło pracowników PKP z sekretarzem Stanisławem Dybowskim, zorganizowane przez delegatów PPR z Dyrekcji Okręgowej PKP w Krakowie ${ }^{56}$.

Oprócz PPR w powiecie dębickim powstały też struktury powiatowe PPS, która w tymże powiecie w 1947 r. liczyła ponad 1000 członków. Zorganizowano również struktury terenowe ruchu ludowego - w 1944 r. powołano SL „Wola Ludu", które po powstaniu w sierpniu 1945 r. Polskiego Stronnictwa Ludowego (przejęło członków SL) rozwijało aktywną działalność na rzecz autentycznej demokracji i suwerenności Polski wobec ZSRR do połowy 1946 r., a później zostało rozbite przez PUBP w Dębicy. Funkcjonowało jeszcze Stronnictwo Pracy, które jednak nie rozwinęło szerszej działalności na terenie powiatu dębickiego ${ }^{57}$. Wszystkie ugrupowania uznawały stopniowo hegemonię polityczną PPR działającej pod sowiecka „ochroną". Tymczasem ludność Dębicy i powiatu dębickiego coraz bardziej zaczęła odczuwać negatywne skutki pobytu i przemarszów oddziałów Armii Czerwonej, zwłaszcza w przypadku bezpieczeństwa i porządku publicznego.

\footnotetext{
${ }^{55}$ APRz, Komitet Powiatowy PPR w Dębicy (dalej: KP PPR D), 196, Protokół z zebrania KP PPR w Dębicy, 25 VI 1945 r.

${ }^{56}$ APRz, KW PZPR, 1/VIII/4, Wykaz ilościowy kół w woj. rzeszowskim wraz z ilością członków, 1946 r.

${ }^{57}$ Dębica. Zarys dziejów..., s. 539-551.
} 


\section{Sowieci a kwestia bezpieczeństwa ludności i porządku publicznego}

Od początku pobytu w powiecie dębickim żołnierze Armii Czerwonej dopuszczali się wielu przestępstw: morderstw, gwałtów, rabunków mienia, pożarów itp. $\mathrm{W}$ walce z tym patologicznym procederem polska administracja państwowa i samorządowa współpracowała z komendantura Armii Czerwonej. W nocy 27 XI 1944 r. pięciu żołnierzy Armii Czerwonej dokonało napadu rabunkowego w gromadzie Krzywa na dom rolnika Józefa Borka, żądając od niego wódki i żywności, a gdy się okazało, że nie miał alkoholu, żołnierze odeszli. Tej samej nocy przyszedł do niego jeden $z$ wcześniej przebywających $u$ niego czerwonoarmistów, który jednak został obezwładniony i rano doprowadzony przez Borka do Komendantury Wojennej w Dębicy ${ }^{58}$. Z kolei 4 grudnia żołnierze sowieccy zabrali z terenu gromad Kozodrza i Boreczek, w gminie Borek Wielki: $6282 \mathrm{~kg}$ ziemniaków, $707 \mathrm{~kg}$ zboża, $3146 \mathrm{~kg}$ słomy, $1880 \mathrm{~kg}$ siana, $159 \mathrm{~kg}$ mięsa oraz zniszczyli 4 pnie pszczół, a także wzięli 16 m płótna, 8 par butów, koc i marynarkę ${ }^{59}$. Oddziały sowieckie domagały się ponadto 900 ton ziemniaków. Nawet tak duży kontyngent praktycznie uniemożliwiał zaopatrzenie ludności cywilnej, której w warunkach działań wojennych groził głód ${ }^{60}$. W innym wypadku jednostka sowiecka $\mathrm{nr} 480473$, stacjonująca w Lubzinie, zniszczyła urządzenia i magazyn mleczarni w tej miejscowości. W czasie pobytu w pomieszczeniach mleczarni Sowieci wyrzucili urządzenia do produkcji i przerobu mleka, w tym trzy wirówki o pojemności 400-600 litrów, które zostały zniszczone i zdekompletowane, wgniatacze do produkcji masła i maselnice pozbawiono części drewnianych, przez co części metalowe zawilgotniały i zardzewiały. Inne urządzenia, jak kosze od wirówek, były używane przez czerwonoarmistów do naczyń na pomyje w stołówce, a bańki na mleko i naczynia mleczarskie zabrała jednostka sowiecka, która miała rzekomo wywieźć je do Żytomierza, co okazało się nieprawdziwą informacja, niemniej jednak Polski Związek Mleczarski prosił władze wojewódzkie o interwencję w tej sprawie ${ }^{61}$. Żołnierze sowieccy zamordowali 27 XII 1944 r. Antoniego Zdziebki mieszkajacego w Niedźwiadzie, a w sprawie jego śmierci śledztwo prowadziła Komenda Powiatowa MO w Ropczycach, przy pomocy Komendantury Wojennej w Dębicy ${ }^{62}$.

58 APRz, Starostwo Powiatowe Dębickie (dalej: SPD), 69/56, Pismo do komendanta wojennego w Dębicy z 5 XII 1944 r., k. 8.

${ }^{59}$ Ibidem, Spis gospodarzy, którym wojska Armii Czerwonej samowolnie zabrały płody rolne i inne [rzeczy - G.B.] w gromadzie Boreczek z 25 XI 1944 r., k. 17-18.

${ }^{60}$ Ibidem, Pismo Starostwa Powiatowego Dębickiego do Urzędu Wojewódzkiego w Rzeszowie z 4 XII 1944 r., k. 13. Nie można tu wykluczyć pomyłki, ponieważ powiat dębicki należał wówczas do województwa krakowskiego.

${ }^{61}$ Ibidem, Pismo Małopolskiego Związku Mleczarskiego do Urzędu Wojewódzkiego w Rzeszowie z 1 XII 1944 r., k. 21.

${ }^{62}$ APRz, SPD, 69/24, Pismo Komendy Powiatowej MO w Ropczycach do Starostwa Powiatowego w Ropczycach z 12 I 1945 r., k. 4. 
Podczas stacjonowania wojsk sowieckich w powiecie dochodziło też do napadów na pociagi. 11 VI 1945 r. na trasie Lubzina-Zawada żołnierz sowiecki Aleksandr Kowalczenko zaczą strzelać do ludzi, zabijając jedna osobę - Marię Klunowską i raniąc trzy kolejne, które po udzieleniu im pomocy lekarskiej wróciły do domów ${ }^{63}$. Często też okolicznych rolników pozbawiali wozów, a takie sytuacje zdarzały się np. w gminach Olchowa i Paszczyna. Na terenie gminy Olchowa żołnierze sowieccy zabrali wozy, którymi na polecenie starosty była przewożona żywność z Mielca dla ludności powiatu dębickiego. W innym wypadku Sowieci wzięli wóz należący do Stefana Wszołka, który przewoził nim osoby wysiedlone w czasie walk styczniowych na stację kolejową w Sędziszowie, i pojechali wraz z nim do Przeworska, zostawiając pasażerów na drodze. W gminie Paszczyna żołnierze jednostki Armii Czerwonej nr 78033 korzystali z wozów do swoich celów, nie licząc się z potrzebami lokalnej społeczności ${ }^{64}$. Gdy doszło do śmiertelnego zatrucia grupy żołnierzy sowieckich samogonem, 26 marca szef PUBP w Dębicy, ppor. Wojtasik zabronił sprzedaży tego alkoholu Sowietom ${ }^{65}$. Chłopi, którzy kupowali konie od żołnierzy za wódkę, musieli je potem oddać do dyspozycji władz, które mogły je przydzielić innym rolnikom. Tak stało się z koniem kupionym za samogon przez Jana Zawiślaka z gromady Róża. Musiał go potem oddać na polecenie starosty dębickiego, w asyście funkcjonariusza MO, rolnikowi Janowi Taborowi, mieszkającemu w Czarnej Tarnowskiej, któremu Sowieci zabrali wcześniej dwa konie ${ }^{66}$.

Czerwonoarmiści doprowadzali do awantur, czego przykładem była sytuacja podczas zabawy tanecznej 15 IV $1945 \mathrm{r}$. w Kawęczynie. W jej trakcie żołnierz sowiecki postrzelił funkcjonariusza Służby Ochrony Kolei, Józefa Siwego, który wezwał na pomoc funkcjonariuszy PUBP w Sędziszowie, Franciszka Kozę i Czesława Kozę. Obaj rozbroili żołnierza i doprowadzili go do więzienia w Dębicy ${ }^{67}$. W tym samym dniu w sassiednim Pilznie przy ul. Lwowskiej sowiecki samochód wojskowy najechał na 36-letnią Marię Chrupek pochodząca z Łąk Górnych. Jak stwierdził w notatce służbowej kpr. Jan Sroka: „Przechodzący przypadkowo Kula Walenty z Pilzna rozpoznał w zabitej swoją służąca [...] a przy denatce znalazłem tylko książeczkę do nabożeństwa”. Niestety, z powodu niewykrycia sprawców śledztwo zostało umorzone ${ }^{68} .19$ kwietnia

${ }^{63}$ Ibidem, Pismo z 11 VI 1945 r., k. 18.

${ }^{64}$ APRz, SPD, 69/56, Pismo Gminnej Rady Narodowej w Olchowej do Starostwa Powiatowego w Dębicy z 5 III 1945 r., k. 2; ibidem, Odpis protokołu z gromady Lubzina z 10 III 1945 r., k. 3.

${ }^{65}$ Ibidem, Pismo szefa PUBP w Dębicy do Starostwa Powiatowego z 26 III 1945 r., k. 4.

${ }^{66}$ Ibidem, Pismo starosty powiatowego do J. Zawiślaka z 11 IV 1945 r., k. 5; ibidem, Pismo Zarządu Gminy Czarna Tarnowska z 11 IV 1945 r., k. 7.

${ }^{67}$ S.M. Jankowski, Dawaj czasy! Czyli wyzwolenie po sowiecku, Poznań 2017, s. 250.

68 Archiwum Narodowe w Krakowie (dalej: ANKr), Prokuratura Sądu Okręgowego w Tarnowie (dalej: PSOT), IV Ds. 126/45, Zgłoszenie wypadku samochodowego z 17 IV 1945 r., k. nlb. 
ok. godz. 6.30 żołnierze sowieccy: sierż. Iwan Cwytkow i chor. Mikołaj Sotnikow z 207 Pułku Piechoty zastrzelili rolnika z Kamienicy Górnej, Władysława Przystasza, który bronił swojego gospodarstwa przed rabusiami w mundurach Armii Czerwonej. W wyniku wspomnianego zajścia chor. Sotnikow został zraniony nożem w brzuch w czasie napadu. Sprawców zabójstwa ujęto, przy czym sierż. Cwytkow został przekazany do dyspozycji komendanta RKU w Dębicy, a chor. Sotnikow odwieziony do Szpitala Miejskiego w Dębicy ${ }^{69}$.

29 czerwca, w lesie położonym w odległości $3 \mathrm{~km}$ od miejscowości Krzywa, nieznany żołnierz sowiecki zgwałcił pod groźbą użycia broni Apolonię Świniuch, która zaszła w ciążę. Niestety, sprawców nie udało się znaleźć, dlatego też śledztwo zostało umorzone ${ }^{70}$. Z kolei w nocy 18/19 lipca trzech oficerów sowieckich, szukajacych rzekomo „kwaterunku z kobietami”, dokonało napadu i próby gwałtu na nieletnich dziewczętach, które - korzystając z zamieszania uciekły wraz ze swoją matką do sąsiedniego mieszkania. Świadek zdarzenia, u którego kwaterował sierżant Armii Czerwonej, podją próbę uzyskania pomocy na milicji, jednak bezskuteczna, ponieważ milicjanci nie zamierzali narażać się Sowietom, a jako pretekst odmowy pomocy użyli argumentu, że jest ich zbyt mało. Świadek zdarzenia, pracownik Wydziału Powiatowego, Mieczysław Dolańczyk mówił, że był wielokrotnie napadany przez żołnierzy sowieckich, zaś oficer napastnik groził mu śmiercią. Mimo tego zagrożenia opisał on całe zajście i zgłosił na milicji, żądając zapewnienia bezpieczeństwa i porządku publicznego na terenie powiatu dębickiego ${ }^{71}$.

Ze względu na znaczną przestępczość w powiecie władze wojewódzkie w Rzeszowie wydały odezwę „Do ogółu ludności województwa rzeszowskiego", w której wezwały mieszkańców do pomocy organom bezpieczeństwa $\mathrm{w}$ walce $\mathrm{z}$ szeroko pojętym bandytyzmem - wliczając $\mathrm{w}$ to również zwalczanie polskiego podziemia niepodległościowego, ale i przestępstw kryminalnych, których sprawcami byli także żołnierze Armii Czerwonej. Wspomniana odezwa została rozwieszona we wszystkich gminach i gromadach powiatu ${ }^{72}$.

Zdarzały się też wypadki samochodowe, które powodowali często pijani kierowcy sowieccy, czego przykładem było śmiertelne potracenie 18 VII 1945 r. wdowy i matki trójki dzieci, N. Jeziorowej, na drodze pomiędzy Dębica a Zawada. Niestety, sprawcy pozostali bezkarni ${ }^{73}$. 22 XI 1945 r. sowiecki

${ }^{69}$ ANKr, PSOT, IV Ds. 117/45, Pismo do Prokuratury Sądu Apelacyjnego w Krakowie z 19 V 1945 r., k. nlb.

${ }^{70}$ ANKr, PSOT, IV Ds. 609/45, Zgłoszenie przestępstwa z 20 VIII 1945 r.; Protokół przesłuchania świadka z 28 V 1946 r., k. nlb.

71 APRz, SPD, 69/24, Pismo Mieczysława Dolańczyka do starosty powiatowego w Dębicy z 19 VII 1945 r., k. 15-16.

72 APRz, SPD, 69/26, Odezwa „Do ogółu ludności województwa rzeszowskiego” z 11 I 1946 r. k. 4; ibidem, Pismo Starostwa Powiatowego Dębickiego do wszystkich burmistrzów i wójtów z 7 II 1946 r., k. 2.

${ }^{73}$ S.M. Jankowski, op. cit., s. 252. 
samochód wojskowy śmiertelnie potrącił w Ropczycach 9-letnią Stanisławę Krzak $^{74}$. W nocy 18/19 X 1945 r. doszło do napadu telefonistów sowieckich na dworcu PKP w Dębicy, którzy chcieli wziąć aparat telefoniczny, aby zadzwonić „ze słupa” (przez nielegalne podłączenie się do sieci telefonicznej). Jednak po interwencji kolejarza Ferdynanda Pikuły u dyżurnego ruchu ten nie wyraził zgody, a wówczas żołnierz sowiecki zerwał kolbą automatu druty telefoniczne i niecenzuralnie wyraził się o polskim kolejarzu, jednak śledztwo w tej sprawie zostało umorzone ,z powodu niewykrycia sprawców”75. Według informacji zawartych w aktach Prokuratury Sądu Okręgowego w Tarnowie żołnierze Armii Czerwonej popełnili: 5 zabójstw, 7 napadów rabunkowych i kradzieży mienia, 2 gwałty, a ponadto spowodowali wiele wypadków samochodowych, w których zginęło 5 osób ${ }^{76}$. Sytuacja pod tym względem zaczęła poprawiać się dopiero od jesieni 1945 r., kiedy to wojska sowieckie w ramach demobilizacji wracały do kraju lub były przenoszone w inne rejony Polski, jako oddziały formowanej wówczas Północnej Grupy Wojsk Armii Czerwonej.

\section{Problemy w gospodarce powiatu dębickiego w okresie pobytu wojsk sowieckich}

Czasowe stacjonowanie wojsk sowieckich w powiecie dębickim odbiło się również negatywnie na życiu gospodarczym całego regionu. Po przejściu frontu i likwidacji okupacji niemieckiej dowódcy oddziałów żądali np. roślin i mięsa do spożycia czy też karmy dla koni. Gmina Pilzno musiała dostarczyć oddziałom Armii Czerwonej $8450 \mathrm{~kg}$ ziemniaków, $1600 \mathrm{~kg}$ siana i $400 \mathrm{~kg}$ słomy, a na potrzeby sowieckiej Wojskowej Grupy Operacyjnej Rozminowania Pól-JW nr 65467 - 5 ton słomy. Na prośbę Zarządu Gminy Pilzno, dotyczącą zapłaty za rzeczone środki, 16 VI 1945 r. strona sowiecka odpowiedziała, że należy zwrócić się w tej sprawie do mjr. Nocenki. Jednostki sowieckie otrzymały od poszczególnych gromad gminy Pilzno $798 \mathrm{~kg}$ zboża, 20,390 kg ziemniaków, $14,950 \mathrm{~kg}$ siana, $900 \mathrm{~kg}$ słomy i $225 \mathrm{~kg}$ jarzyn $^{77}$. W gminie Paszczyna kontyngent płodów rolnych, przeznaczony dla Armii Czerwonej, został pokryty w ok. $45 \%$ przez gminę. Ponadto oddziały sowieckie zabrały bez pokwitowania z pól, budynków gospodarczych płody rolne w wysokości o 55\% większej niż założona

\footnotetext{
${ }^{74}$ ANKr, PSOT, IV Ds. 896/45, Protokół przesłuchania świadka z 29 XI 1945 r.; Wniosek o umorzenie dochodzenia z 3 XII 1945 r., k. nlb.

75 ANKr, PSOT, III Ds. 689/45, Protokół przesłuchania świadka z 4 X 1945 r., k. nlb. Por. S.M. Jankowski, op. cit., s. 253.

${ }^{76}$ Zestawienie własne na podstawie akt Prokuratury Sądu Okręgowego w Tarnowie z 1945 r.

${ }^{77}$ ANKr, Urząd Wojewódzki Krakowski II (dalej: UWKr II), 1809, Pismo Zarządu Gminy Pilzno do mjr. Nacenki z 4 VII 1945 r., k. 97; ibidem, Wykaz dostaw artykułów dla Armii Czerwonej za czas od 2 II do 15 VIII 1945 r., k. 103-105; Zestawienie [świadczeń na rzecz Armii Czerwonej - G.B.] z 28 VIII 1945 r., k. 107.
} 
przez władze administracyjne powiatu. Dodatkowo wobec całkowitego lub częściowego wysiedlenia niektórych gromad - Brzozówki, Brzeźnicy, Lubziny i Paszczyny - Sowieci nie tylko pobrali samowolnie pozostawione płody rolne, ale i nie zabezpieczyli pozostałych płodów, jak np. ziemniaków w kopcach, które zamarzły. Wysokość strat z tego tytułu, w stosunku do nałożonego kontyngentu, wyniosła $20 \%$. Podczas marszu wojska sowieckie stratowały 795 ha upraw $(35 \%)^{78}$. Podobnie sytuacja wyglądała w gminie Straszęcin, gdzie lokalni dowódcy sowieccy zarządzili ewakuację ludności, która zostawiła płody rolne w gospodarstwach, zrabowane następnie przez głodnych żołnierzy ${ }^{79}$.

Przez teren powiatu dębickiego odbywały się także przepędy zdobycznego inwentarza żywego z Niemiec i Polski do ZSRR. W związku z tym żołnierze skarmiali pędzone bydło i konie, często samowolnie kosząc na potrzeby wyżywienia zwierząt koniczynę, trawy, zboża czy tė zabierając siano. Wyniszczenie zbóż ozimych i jarych nie pozostało też bez wpływu na sytuację aprowizacyjna powiatu. Jeśli dodać do niej liczne, wspomniane przestępstwa, popełniane przez wkraczających, a potem powracających z wojny żołnierzy sowieckich, to były podstawy do nieufności wobec nich ze strony mieszkającej tam ludności ${ }^{80}$. Ponadto żołnierze sowieccy pobierali nielegalnie drzewo z okolicznych lasów (obok miejscowej ludności), o czym 9 III 1945 r. wspominał w sprawozdaniu nadleśniczy Lasów Państwowych w Dębicy ${ }^{81}$. Władze powiatu wydzierżawiły na rzecz Armii Czerwonej 34,13 ha ziemi w parcelowanym majątku w Poddębach ${ }^{82}$.

W maju 1946 r. Powiatowy Urząd Ziemski w Dębicy przesłał do Wojewódzkiego Urzędu Ziemskiego w Rzeszowie wykazy strat spowodowanych przez stacjonujace w powiecie jednostki Armii Czerwonej. Od 9 V 1945 r. do 20 V 1946 r. w Ośrodkach Kultury Rolnej (OKR) w Górze Ropczyckiej, Zawadzie-Straszęcinie, Strzegocicach i Iwierzycach łącznie w przeliczeniu na wartość kilograma żyta wyniosły one $3,002,06 \mathrm{~kg}^{83}$.

Należy zwrócić uwagę na brak zajęcia przez wojska sowieckie państwowego majątku w Górze Ropczyckiej, natomiast majątek Państwowej Stadniny Koni w Zawadzie-Straszęcinie był pod polskim zarządem, zaś majątek OKR w Strzegocicach w dniach 29 VI - 9 VII 1945 r. zajmował i eksploatował oddział Armii Czerwonej. Z majątku w Górze Ropczyckiej żołnierze sowieccy

\footnotetext{
78 APRz, WPD, 56/96, Sprawozdanie Zarządu Gminy Paszczyna z 14 IV 1945 r., k. 15.

${ }^{79}$ Ibidem, Sprawozdanie z położenia gminy Straszęcin z 23 III 1945 r., k. 31.

${ }^{80}$ ANKr, UWKr II, 919, Sprawozdanie sytuacyjne za okres do 30 VI 1945 r., k. 47; ibidem, Sprawozdanie sytuacyjne za miesiac lipiec 1945 r., k. 55-57.

${ }^{81}$ APRz, PRN w Dębicy, 56/1, Protokół z obrad planarnego zebrania Powiatowej Rady Narodowej z 8-10 III 1945 r., k. 15.

${ }^{82}$ Ibidem, Sprawozdanie z przebiegu parcelacji w powiecie dębickim z końca maja 1945 r., k. 32.

${ }^{83}$ APRz, Wojewódzki Urząd Ziemski w Rzeszowie (dalej: WUZ Rz), 152/310, Pismo Powiatowego Urzędu Ziemskiego w Dębicy do Wojewódzkiego Urzędu Ziemskiego w Rzeszowie z 23 V 1946 r., k. 1.
} 
zabrali m.in. owoce, warzywa i ryby, zniszczyli też stajnię i częściowo rozebrali stodołę, natomiast zboże, ziemniaki, jarzyny, sprzęty gospodarskie zarekwirowali we wszystkich majątkach tego powiatu ${ }^{84}$.

Powiat dębicki należał do dość intensywnie uprzemysłowionych regionów Polski, a na jego terenie istniały zakłady COP, w tym Fabryka Opon Samochodowych „Stomil” i Wytwórnia Urządzeń Chłodniczych (WUCh), a także zakłady zaliczane do tzw. przemysłu terenowego, w tym cegielnie, betoniarnie, młyny, tartaki itp. ${ }^{85} \mathrm{~W}$ powiecie dębickim było 71 obiektów tego rodzaju przemysłu, w tym 39 młynów (10 elektrycznych, 20 wodnych, 9 parowych), 5 mleczarni, 6 gorzelni, bekoniarnia, olejarnia, a oprócz zakładów przemysłu spożywczego też 10 tartaków, 2 betoniarnie i 7 cegielni ${ }^{86}$.

Straty w zakresie przemysłu w powiecie dębickim były spowodowane, głównie w okresie okupacji niemieckiej, przez wywóz maszyn i urządzeń do Rzeszy, a w latach 1944-1945 wskutek działań wojennych lub celowego niszczenia urządzeń przez wycofujących się Niemców, a potem przychodzących Sowietów. Przykład niszczycielskich działań ze strony żołnierzy Armii Czerwonej stanowiła PPM w Dębicy. Po zajęciu miasta żołnierze sowieccy ulokowani na terenach PPM zniszczyli w 20\% budynki, w $60 \%$ - urządzenia i $80 \%$ - maszyny. $Z$ terenu zakładu oddział wojsk zdobycznych wywiózł: 3 kotły parowe o powierzchni ogrzewalnej $300 \mathrm{~m}, 4$ maszyny parowe o sile $34 \mathrm{KM}, 38$ maszyn elektrycznych o łącznej sile $136,7 \mathrm{KM}, 7$ pomp, 39 różnego rodzaju wag, 18 maszyn masarskich różnego typu, a także kompletne urządzenia i maszyny z warsztatów mechanicznego i stolarskiego ${ }^{87}$.

W takim stanie technicznym Centralny Zarząd Przemysłu Konserwowego przeją 15 X 1945 r. obiekty PPM, rozpoczynając przywracanie zakładów do życia gospodarczego. Dzięki ofiarności jego pracowników i dyrekcji została ona odbudowana własnym wysiłkiem, bez korzystania z kredytów państwowych. Ponieważ maszyny i urządzenia, zdemontowane i wywiezione w latach 1944-1945 przez wojska zdobyczne Armii Czerwonej, były nie do odzyskania w warunkach braku suwerenności Polski pod rząami komunistów, PPM zakupiła je na Górnym Ślasku i we Wrocławiu ${ }^{88}$. Również gorzelnictwo poniosło straty wojenne i powojenne - zarówno od Niemców, jak i Sowietów, czego przykładem były gorzelnie w majątku hr. Raczyńskiego w Zawadzie, gdzie łączne straty wyniosły $70650 \mathrm{zł}$, oraz w Latoszynie - 37 tys. zł, liczone według cen z 1939 r. $^{89}$

${ }^{84}$ Ibidem, k. 4-7.

${ }^{85}$ APRz, Urząd Wojewódzki Rzeszowski, 983, Spis zakładów przemysłowych w powiecie dębickim, lipiec 1945 r., k. 1-210.

${ }^{86}$ APRz, WUZ Rz, 152/45, Wykaz przedsiębiorstw n terenie powiatu dębickiego z 8 I 1946 r., k. 2. Zob. A. Żerbecka, Monografia miasta Dębicy, „Zeszyty Dębickie” 2000, nr 1, s. 16-28.

${ }^{87}$ A. Żerbecka, op. cit., s. 19.

${ }^{88}$ Ibidem.

${ }^{89}$ Ibidem, s. 22. 
W latach trzydziestych w Polsce zaczęła rozwijać się produkcja sztucznego kauczuku, a jesienia 1938 r. rozpoczęto ją w powstałych Zakładach Chemicznych (ZCh) w Dębicy. Wybuch wojny i działania wojenne 1939 r. nie zniszczyły obiektów fabrycznych, jednak w okresie okupacji niemieckiej - mimo nacisków władz okupacyjnych - fabryka nie podjęła produkcji sztucznego kauczuku. W odwecie Niemcy zaczęli dewastować fabrykę, zamieniając jej obiekty w dużą stację benzynową przez częściowe dostosowanie urządzeń do tego celu oraz zwożąc maszyny i urządzenia z innych fabryk, a wśród nich urządzenia fabryczne, instalacje ruchowe i aparaturę badawczą ZCh w Dębicy. Straty były ocenianie na 60\% wartości, w kwocie 800 tys. zł przedwojennych. Po przejściu frontu i zajęciu obiektów ZCh przez wojska sowieckie, oddziały zdobyczne Armii Czerwonej nadal dewastowały fabrykę, wywożąc to, co jeszcze można było zabrać i dopiero w grudniu $1946 \mathrm{r}$. została przejęta od sowieckich władz wojskowych przez zarząd polski pod przewodnictwem inż. Werbachowskiego. Wówczas zaczął się okres powojennej odbudowy fabryki, która weszła w skład Zjednoczenia Przemysłu Gumowego i Tworzyw Sztucznych w Łodzi ${ }^{90}$.

Po zajęciu zachodniej części miasta przez Armię Czerwoną w styczniu 1945 r. władze administracyjne obawiały się demontaży i wywozu maszyn z dębickiej Fabryki Gum Jezdnych. W związku z tym zagrożeniem jej pracownicy powołali straż w celu zabezpieczenia mienia, którego Niemcy nie zdążyli wywieźć w końcu 1942 r. do Rzeszy. Na miejscu zdewastowanej fabryki Niemcy utworzyli warsztaty naprawcze. W latach 1944-1945 przez teren fabryki przebiegała linia frontu, co doprowadziło do poważnych zniszczeń jej obiektów, zaś łączne straty sięgnęły sumy 4 mln zł według cen z 1939 r. Oficjalnie pracownicy zostali zatrudnieni w lipcu, gdy do zakładów przyjechał dyrektor poznańskiego „Stomilu”, Jan Marciniak, w celu dokonania oceny jej obiektów, choć ostateczna decyzja o jej odbudowie zapadła w 1946 r. Urzadzenia i maszyny, wywiezione w 1944 r. przez wojska niemieckie, zostały odnalezione podczas rewindykacji przez polsko-angielska komisję w zakładach IG Farbenindustrie w Leverkusen i Ludwigshafen, w angielskiej strefie okupacyjnej Niemiec. Po zaspokojeniu pretensji finansowych, zgłoszonych przez firmę angielską Francis Shaw Co Ltd Manchester i regulacji należności kredytowych, w $1948 \mathrm{r}$. strona polska przystapiła do rewindykacji maszyn i urządzeń, uruchamiając próbnie zakład w 1949 r., a rok później rozpoczynając produkcję opon samochodowych, przerwaną w 1939 r. ${ }^{91}$

W ramach budowy COP, w latach 1938-1939, w Pustyni powstała też walcownia metali, w której w ostatnich tygodniach przed wybuchem wojny trwał rozruch produkcji w działach gotowych do jej podjęcia. W chwili wybuchu

\footnotetext{
90 Ibidem, s. 23.

${ }^{91}$ Ibidem, s. 24. Zob. Dębickie Zakłady Opon Samochodowych „Stomil” 1939-1989, RzeszówDębica 1989, s. 15-16.
} 
wojny na składach fabrycznych znajdowało się $4331111 \mathrm{~kg}$ miedzi i $950000 \mathrm{~kg}$ cynku elektrolitowego, które to zapasy wraz z maszynami i urządzeniami na przełomie lat 1939-1940 Niemcy wywieźli do Rzeszy, urządzając w zakładzie składy zbożowe, które w 1944 r. zabrali do Niemiec. Wiosną 1944 r. Niemcy urządzili tam artyleryjskie warsztaty naprawcze zatrudniające ok. 1000 osób, w tej liczbie wojskowych, ludność cywilną i jeńców sowieckich. Po zajęciu tego terenu przez Armię Czerwoną w sierpniu 1944 r., Sowieci stacjonowali w nich do marca $1945 \mathrm{r}$., potem zaś rozpoczą się okres odbudowy, a z dniem 1 I 1947 r. budynki Walcowni Metali w Pustyni przejęło Zjednoczenie Przemysłu Metali Nieżelaznych w Katowicach ${ }^{92}$. Ogromne straty poniosła też Wytwórnia Tworzyw Sztucznych „Lignoza” w Pustkowie, z której w 1939 r. Niemcy wywieźli maszyny i urządzenia, przeznaczając obiekt od 1940 r. na plac ćwiczeń wojskowych - „Truppenubungsplatz”, gdzie stacjonowały oddziały Wehrmachtu i SS. Na jej terenie były też obóz pracy przymusowej i obóz jeniecki, w którym od 1941 r. przebywali jeńcy sowieccy. Niemcy zbudowali tu również wyrzutnie broni rakietowej V1, wystrzeliwując je w latach 1943-1944 m.in. na Londyn. Podczas działań wojennych lat 1944-1945 fabryka została w 40\% zniszczona, jednak po odzyskaniu w 1945 r., w ramach reparacji wojennych, maszyn i urządzeń z Niemiec rozpoczęła się jej odbudowa ${ }^{93}$. W całym regionie dębickim następowała też odbudowa zakładów przemysłowych. W tym kontekście wycofanie oddziałów Armii Czerwonej z powiatu przyspieszyło proces zarówno odbudowy przemysłu, jak i pozostałych gałęzi gospodarki, nie mówiąc już o bezpieczeństwie ludności.

\section{Podsumowanie}

Podsumowując opisywana problematykę, należy stwierdzić, że w latach 1944-1945 zarówno NKWD, jak i oddziały Armii Czerwonej wpłynęły zdecydowanie negatywnie na sytuację społeczno-polityczną i ekonomiczną powiatu dębickiego. W zakresie społeczno-politycznym placówka NKWD miała wpływ zarówno na powstanie, organizację i działalność komunistycznych organów bezpieczeństwa: MO, a zwłaszcza PUBP, wspierała również czynnie i logistycznie zwalczanie struktur PPP i AK, organizację deportacji dowódców i żołnierzy AK, Batalionów Chłopskich i NSZ do ZSRR. Sowieci również wpłynęli w sposób negatywny na bezpieczeństwo ludności i sytuację społeczno-ekonomiczną tego powiatu. Zarówno dowódcy, jak i żołnierze sowieccy dopuszczali się różnych przestępstw: morderstw, gwałtów, kradzieży, rabunków i napadów na mieszkańców Dębicy i powiatu dębickiego. Doszło do rabunków mienia gospodarczego, które szczególnie odczuł sektor rolny jako podstawowa

\footnotetext{
${ }_{92}$ A. Żerbecka, op. cit., s. 26-27.

${ }^{93}$ Ibidem, s. 25.
} 
gałą́ gospodarki. Oddziały wojsk zdobycznych Armii Czerwonej dokonywały przepędu zdobycznego inwentarza żywego, głównie z Niemiec do ZSRR, skarmiając podczas drogi bydło i konie na polach należących do rolników, którzy musieli dodatkowo dostarczać państwu tzw. dostaw obowiąkowych zbóż, roślin okopowych i pastewnych, w znacznej części wykorzystywanych przez oddziały wojsk sowieckich. Zarówno stacjonujące, jak i przejeżdżające oddziały sowieckie rabowały również mienie gospodarcze, w tym pasy transmisyjne, maszyny i sprzęty rolnicze, zbiory plonów, inwentarz żywy itd. Kres tym praktykom położyło wycofanie wojsk sowieckich z powiatu dębickiego pod koniec $1945 \mathrm{r}$.

\section{Streszczenie}

Niniejszy artykuł poświęcony jest skutkom czasowego pobytu oddziałów Armii Czerwonej w powiecie dębickim w latach 1944-1945. Autor we wprowadzeniu ukazał rys historyczny Dębicy na tle historii Polski. W zasadniczej części opisał wpływ wojsk sowieckich i organów bezpieczeństwa ZSRR, przebywających na terenie tego powiatu, na sytuację społeczno-polityczna, bezpieczeństwo mieszkańców i życie gospodarcze. Jeśli chodzi o kwestie geopolityczne, Autor ukazał wpływ sowieckiej komendantury wojennej i NKWD na budowę podstaw totalitarnego systemu komunistycznego na terenie powiatu dębickiego, w tym zarówno powstanie organów bezpieczeństwa, jak i lokalnej organizacji partyjnej Polskiej Partii Robotniczej oraz jej rolę w umacnianiu władzy komunistów z równoczesną likwidacją struktur Polskiego Państwa Podziemnego, Armii Krajowej i podziemia narodowego. W tekście opisano również liczne przestępstwa, których dopuścili się żołnierze sowieccy $\mathrm{w}$ tym powiecie wobec jego mieszkańców, jak: zabójstwa, rabunki i napady, gwałty czy wypadki samochodowe, w których zginęli niewinni ludzie. W ostatniej części artykułu Autor ukazał wpływ oddziałów sowieckich na życie społeczno-gospodarcze, podając przykłady rabunków mienia gospodarczego, które negatywnie wpłynęły na powojenny rozruch gospodarczy, a tym samym opóźniły odbudowę powiatu - zwłaszcza rolnictwa, gdzie szkody były największe. Artykuł kończy krótkie podsumowanie opisywanej problematyki.

\section{The Town and District of Dębica under the Rule of the Red Army in 1944-1945 in Socio-Political and Economic Aspects}

The article deals with the effects of the stay of Red Army troops in the District of Dębica in 1944-1945. In his introduction, the author presents an outline of history of the town of Dębica against the background of Polish history in general. In its main part, he describes the impact of the Soviet troops and the Soviet security services staying in the district on the socio-political situation as well as on the security of the local population and the economic life in the district. Regarding geopolitical issues, the author shows the influence of the Soviet war command and NKVD on the foundations of a totalitarian communist system in the District of Dębica, including both the creation of security organs as well as the local party organization of the Polish Workers' Party and its role in strengthening the power of the communists with the simultaneous liquidation of the structures of the Polish Underground State, Home Army and national underground. He also describes numerous crimes committed by Soviet soldiers in the district against its inhabitants, such as murders, robberies and assaults, rapes or car accidents in which innocent people were killed. In the last part of the 
article, the author presents the impact of Soviet troops on socio-economic life, illustrating the text with examples of robberies of economic property that negatively affected the post-war economic start-up, and thus delayed the post-war economic reconstruction of the district especially in the agriculture sector, where the damage was the greatest. The article ends with a brief summary of the described issues.

\section{Bibliografia}

Bata A., Lawera H., Dębica i ziemia dębicka, Krosno 1997.

Biedroń T., Okręg Krakowski Narodowych Sit Zbrojnych w latach 1945-1946, „Zeszyty Historyczne WiN-u" 1993, nr 3.

Daszkiewicz A., Międzypartyjne stosunki polityczne w Polsce Południowo-Wschodniej (lata 1944-1947), Rzeszów 1987.

Daszkiewicz A., Życie polityczne w latach 1944-1948, w: Ropczyce. Zarys dziejów, red. W. Bonusiak, F. Kiryk, Rzeszów 1991, s. 405-432.

Dębica. Zarys dziejów miasta i regionu, red. J. Buszko, F. Kiryk, Kraków 1995.

Dębickie Zaktady Opon Samochodowych „Stomil” 1939-1989, Rzeszów-Dębica 1989.

Dobosz S., Przemiany polityczno-społeczne w Matopolsce Środkowej w latach 1944-1950, Rzeszów 1990.

Dymitrowski J., Publiczna egzekucja w Dębicy, cz. 2, s. 6, https://glos24.pl/glos24/region-debicki/ wiadomosci/item/8173-publiczna-egzekucja-w-d\%C4\%99bicy-cz-2 (dostęp: 10 VIII 2018).

Fiołek E., Przywódcy WiN-u. Antoni Waratus, ps. „Obuch”, „Bujnicz”, „Orzeł Biały”, XII 1992, nr 1215.

Frazik W., Z dziejów łaczności cywilnej Kraj - emigracja w latach 1944/1945-1948/1949, „Zeszyty Historyczne WiN-u” 1998, nr 11.

Gałas E., Rola PPR w budowie władzy ludowej w pow. Dębica, w: Działalność PPR na Ziemi Rzeszowskiej (szkice, opracowania, wspomnienia), red. B. Syzdek, Warszawa 1976, s. 177-230.

Gałas E., Tak rodziła się władza ludowa w Dębickiem, w: Materiały z sesji popularnonaukowej poświęconej zagadnieniom kształtowania się wtadzy ludowej na Rzeszowszczyźnie, Rzeszów 1966.

Informator o nielegalnych antypaństwowych organizacjach $i$ bandach zbrojnych dziatajacych $w$ Polsce Ludowej w latach 1944-1956, Warszawa 1964.

Jankowski S.M., Dawaj czasy! Czyli wyzwolenie po sowiecku, Poznań 2017.

Jaśniak J., Tajemnica lasu Turzańskiego, „Katolik”, 26 VIII 1990, nr 34 (409).

Korkuć M., „Zostańcie wierni tylko Polsce...” Niepodlegtościowe oddziały partyzanckie w Krakowskiem (1944-1947), Kraków 2002.

Kulińska L., Narodowcy. Z dziejów Obozu Narodowego w Polsce w latach 1944-1947, Kraków 1999.

Lubiniecki A., Organizacja i działalność organów bezpieczeństwa publicznego na Rzeszowszczyźnie w latach 1944-1946, w: Materiaty z sesji popularnonaukowej poświęconej zagadnieniom kształtowania się władzy ludowej na Rzeszowszczyźnie, Rzeszów 1966, s. 217-228.

Maciaga M., Sprawa trzech od „Mściciela”, „Katolik”, 24 XI 1989, nr 39 (362).

Narodowe Zjednoczenie Wojskowe, w: Żotnierze wyklęci. Antykomunistyczne podziemie zbrojne po 1944 roku, red. G. Wassowski, L. Żebrowski, Warszawa 1999, s. 141-215.

Ostasz G., O WIN-owskim kolportażu w Okręgu Rzeszów, „Orzeł Biały” 1993, nr 6 (21).

Paczkowski A., Pót wieku dziejów Polski 1939-1989, Warszawa 2005.

Polskie Sity Zbrojne w drugiej wojnie światowej, t. III: Armia Krajowa, Londyn 1950.

Rojek W., Stronnictwo Narodowe (SN) „Kwadrat”, w: Stownik historii Polski, red. A. Chwalba, T. Gąsowski, Kraków 1996, s. 203-209. 
Siemaszko Z.S., Narodowe Sity Zbrojne, Londyn 1982.

Stańko A., Gdzie Karpat progi... Armia Krajowa w powiecie dębickim, Warszawa 1984.

Wolfram T., Koniec NSZ, „Karta” 1991, nr 3.

Żerbecka A., Monografia miasta Dębicy, „Zeszyty Dębickie” 2000, nr 1.

Bi o g r a m: Grzegorz Baziur - dr; starszy wykładowca w Instytucie Nauk Humanistycznych i Społecznych im. Jana Karskiego Małopolskiej Uczelni Państwowej im. rotmistrza Witolda Pileckiego w Oświęcimiu. W badaniach koncentruje się na stosunkach polsko-rosyjskich i polsko-sowieckich w XX-XXI w., systemach totalitarnych, mechanizmach działania i percepcji społecznej, antykomunistycznej konspiracji wśród młodzieży w PRL oraz problemach geopolityki i spraw etnicznych państw Europy Środkowej i Wschodniej. E-mail: baziurg64@gmail.com. 